\title{
Magnolol pretreatment attenuates heat stress-induced IEC-6 cell injury*
}

\author{
Chen MEI ${ }^{1}$, Sha-sha $\mathrm{HE}^{2}$, Peng $\mathrm{YIN}^{2}$, Lei XU ${ }^{1}$, Ya-ran $\mathrm{SHI}^{1}$, Xiao-hong YU \\ An LYU ${ }^{1}$, Feng-hua LIU ${ }^{\dagger 1}$, Lin-shu JIANG ${ }^{\dagger 1}$ \\ ( ${ }^{1}$ Beijing Key Laboratory for Dairy Cow Nutrition, College of Animal Science and Technology, Beijing University of Agriculture, Beijing 102206, China) \\ $\left({ }^{2}\right.$ College of Veterinary Medicine, China Agricultural University (CAU), Beijing 100193, China) \\ †E-mail: liufenghua1209@126.com; jls@bac.edu.cn \\ Received Oct. 31, 2015; Revision accepted Jan. 22, 2016; Crosschecked May 12, 2016
}

\begin{abstract}
Objective: Heat stress (HS) is an important environmental stressor that adversely influences livestock during the summer. The aim of this study was to investigate whether magnolol protects against HS-induced intestinal epithelial cell injury. Materials and methods: An intestinal epithelial cell line (IEC-6) was subjected to $\mathrm{HS}$ at $42^{\circ} \mathrm{C}$, with and without magnolol pretreatment. Cell injury was detected by monitoring lactate dehydrogenase (LDH) release. MTS (3-(4,5-dimethylthiazol-2-yl)-5-(3-carboxymethoxyphenyl)-2-(4-sulfophenyl)-2H-tetrazolium) assay was used to assess cell proliferation and viability, including identifying effective concentrations of magnolol. Flow cytometry confirmed G1-phase cell-cycle arrest and its alleviation by magnolol. Active DNA synthesis was measured by incorporation of nucleic acid 5-ethynyl-2'-deoxyuridine (EdU). G1-phase cell-cycle-related gene expression was assessed by real-time reverse transcription polymerase chain reaction (RT-PCR) and levels of G1-phase-related proteins by Western blotting. Results: HS induced IEC-6 cell injury and decreased cell viability, as demonstrated by data from LDH and MTS assays, respectively. Based on a number of criteria, IEC-6 cells subjected to HS were arrested in the G1 phase of the cell cycle. Magnolol pretreatment decreased HS-induced cell injury through relief of this cell-cycle arrest. Conclusions: Magnolol pretreatment attenuates HS-induced injury in IEC-6 cells. Magnolol is potentially promising as a protective strategy for HS in livestock.
\end{abstract}

Key words: Cell-cycle arrest, Cell injury, Heat stress, IEC-6 cell line, Magnolol http://dx.doi.org/10.1631/jzus.B1500261

CLC number: S85

\section{Introduction}

In summer, heat stress (HS) is a major factor adversely affecting livestock and poultry growth and health (Min et al., 2015). One of the problems is that HS makes animals vulnerable to various infectious

\footnotetext{
* Corresponding authors

* Project supported by the National Natural Science Foundation of China (No. 31272478), the National Twelve-Five Technological Supported Plan of China (No. 2013BAD10B04), the Ministry of Agriculture, Public Service Sectors Agriculture Research Projects (No. 201403051-07), and the Importation and Development of High-Caliber Talents Project of Beijing Municipal Institutions (No. CIT\&TCD20130324), China

(D) ORCID: Feng-hua LIU, http://orcid.org/0000-0002-6428-4052

(c) Zhejiang University and Springer-Verlag Berlin Heidelberg 2016
}

diseases. Recent research has shown that HS caused remarkable pathological damage to the glandular stomach, duodenum, and jejunum (Song et al., 2012; Lei et al., 2013). Such damage was characterized by mucosal epithelial cell detachment, edema of the lamina propria, and intestinal villus breakage ( $\mathrm{Yu}$ et al., 2010). In animals subjected to HS, gastrointestinal ischemia is the first effect, followed by injuries, such as cell membrane damage (Guyot et al., 2015; Yin et al., 2015c), DNA injury (Zhang M.H. et al., 2015), abnormal gene expression, and cell apoptosis (Gao et al., 2015; Sun et al., 2015; Yin et al., 2015a). Therefore, identification of strategies to repair injured intestinal epithelial cells after HS would protect animal health significantly (Yin et al., 2015b). 
Plants are among the most important potential sources of anti-HS drugs (Pan et al., 2014; Song et al., 2014). Magnolol (Mag) (Fig. 1) is the main and active ingredient in magnolia bark. In several studies, Mag was effective against inflammation (Wang et al., 2015), allergy (Chen et al., 2006), stress (Chang et al., 2003), tumors (Wu et al., 2014), and diarrhea (Guerra-Araiza et al., 2013; Xia et al., 2014). Other evidence showed that Mag could reduce HS-induced ischemic injuries (Lee et al., 2013). In addition, Mag prevented cerebral injury caused by HS in rats and increased survival in murine sepsis (Kong et al., 2000; Chang et al., 2003). However, whether Mag could prevent the intestinal epithelial cell line (IEC-6) cell growth inhibition associated with HS-induced cell injury has not been reported.

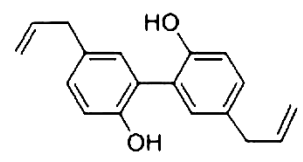

Fig. 1 Structure of Mag

\section{Materials and methods}

\subsection{Cell culture and processing}

Cells from a rat small intestinal epithelial cell line (IEC-6, CRL21592, Peking Union Medical College, Beijing, China) were cultured at $37^{\circ} \mathrm{C}$ in a humidified incubator (Thermo, Marietta, Ohio, USA) equilibrated with $5 \% \mathrm{CO}_{2}$. Cultures were grown and maintained in a complete growth medium consisting of Dulbecco's modified Eagle's medium (DMEM) with 5\% fetal bovine serum (Peking Union Medical College), $2 \mu \mathrm{g} / \mu \mathrm{l}$ insulin (China Agriculture University, Beijing, China), $50 \mathrm{IU} / \mathrm{ml}$ penicillin (China Agriculture University), and $50 \mu \mathrm{g} / \mathrm{ml}$ streptomycin (China Agriculture University). The medium was changed three times per week, according to a standard cell culture protocol. IEC-6 cells were treated in five different groups: control, HS, and HS pretreated with Mag at three concentrations as indicated for the individual experiments. Cells in the control group remained in the $37^{\circ} \mathrm{C}$ incubator. Cells in the HS groups were incubated at $42{ }^{\circ} \mathrm{C}$ for $3 \mathrm{~h}$, equilibrated with $5 \%$ $\mathrm{CO}_{2}$ as for the control cells. Cells in the Mag groups were pretreated with Mag at concentrations indicated in the individual experiments for $3 \mathrm{~h}$, then subjected to HS as described for the HS group. Changes in cell morphology following HS were observed using a phase-contrast inverted biological microscope (IX71/ IX2, Olympus, Beijing, China).

\subsection{MTS cell proliferation assay}

After reaching at least $90 \%$ confluence, cells were washed with phosphate buffer solution (PBS), dissociated with $0.05 \%$ pancreatic enzymes as described above and suspended in a complete growth medium. Cells were plated, at about 5000 cells in $100 \mu \mathrm{l}$ per well, onto a 96-well plate. Cells were incubated for 24,48 , and $72 \mathrm{~h}$ at $37{ }^{\circ} \mathrm{C}$ in the humidified $5 \%$ $\mathrm{CO}_{2}$ equilibrated incubator and then treated with various concentrations of Mag (Beijing Municipal Food and Drug Administration, Beijing, China) for an additional 24,48 , or $72 \mathrm{~h}$, as indicated. After these incubations, $20 \mu \mathrm{l}$ MTS (3-(4,5-dimethylthiazol-2-yl)-5(3-carboxymethoxyphenyl)-2-(4-sulfophenyl)-2Htetrazolium, inner salt) reagent was added to each well. The cells were returned to the incubator for $1-4 \mathrm{~h}$ and then absorbance was read at $490 \mathrm{~nm}$ in a plate reader (BioTek, Vermont, USA).

\subsection{Cell counting}

After reaching at least $90 \%$ confluence, cells were suspended in a complete growth medium. Trypan blue ( $100 \mu \mathrm{l}$ of a $0.1 \%$ solution) was added to $100 \mu \mathrm{l}$ of the cell suspension and gently mixed. Cells were then counted with a hemocytometer, as per the manufacturer's instructions.

\subsection{Lactate dehydrogenase release}

This assay used cells in a logarithmic phase growth on a 96 -well plate. At about $80 \%$ confluence, cells were washed once with PBS and then lactate dehydrogenase $(\mathrm{LDH})$ release was assessed under various treatments using an $\mathrm{LDH}$ kit (Sigma, St. Louis, MO, USA) according to the manufacturer's instructions. The treatment groups were: control, HS, HS with three concentrations of Mag, and a maximum LDH release control group. Absorbance representing released LDH was read at $490 \mathrm{~nm}$.

\subsection{EdU incorporation}

Cells on a 96-well plate were treated as follows: control, HS, and HS after pretreatment with Mag at 
three different concentrations as indicated in the figure legends. DNA synthesis was determined using an EdU kit (RIBOBIO, Beijing, China), measuring incorporation of the nucleotide 5-ethynyl-2'-deoxyuridine (EdU). Changes in cell morphology were observed under a phase-contrast inverted biological microscope.

\subsection{Flow cytometry}

To determine cell cycle status, IEC-6 cells were divided into the following groups, treated as described above: control, HS, and HS with three effective concentrations of Mag. Cells were dissociated and suspended. Following these treatments, cells were washed twice with PBS and fixed overnight in 70\% ethyl alcohol. Cells were then washed with PBS and stained with propidium iodide (PI, Invitrogen, Carlsbad, CA, USA). Fluorescence-activated cell sorting (FACS) analysis was performed according to the manufacturer's instructions (Beckman Coulter Inc., CA, USA).

\section{7 mRNA reverse transcription and expression of cell-cycle genes}

Total RNA was isolated from IEC-6 cells with TRIzol reagent (Invitrogen). RNA concentration was measured with a spectrophotometer (SmartSpec Plus, Bio-Rad, Hercules, CA, USA) using the optical density ratio at $260 \mathrm{~nm}$ and $280 \mathrm{~nm}\left(\mathrm{OD}_{260} / \mathrm{OD}_{280}\right)$. Then further steps were carried out based on the manufacturer's instructions (Promega, Madison, WI, USA). The reverse transcription (RT) reaction was conducted at $42{ }^{\circ} \mathrm{C}$ for $2 \mathrm{~h}$. The RT products (complementary DNA (cDNA)) were stored at $-20^{\circ} \mathrm{C}$ for subsequent polymerase chain reaction (PCR).
Quantitative real-time reverse transcription PCR (qRT-PCR) analysis was performed with a DNA Engine $\mathrm{Mx3000 \textrm {P }}$ fluorescence detection system (Agilent Technologies Co., Ltd., Palo Alto, CA, USA) according to optimized PCR protocols. The PCR reaction system $(20 \mu \mathrm{l}$ total) contained $10 \mu \mathrm{l}$ SYBR Green qPCR mix, $0.3 \mu$ reference dye, $1 \mu$ primer (each at $10 \mathrm{mmol} / \mathrm{L}$ ), and $1 \mu \mathrm{l}$ cDNA template. $\mathrm{Cy}-$ cling conditions were: $95{ }^{\circ} \mathrm{C}$ for $5 \mathrm{~min}$, followed by 40 cycles of $95^{\circ} \mathrm{C}$ for $20 \mathrm{~s}, 55^{\circ} \mathrm{C}$ for $15 \mathrm{~s}$, and $72{ }^{\circ} \mathrm{C}$ for $20 \mathrm{~s}$. Dissociation was initiated at $95{ }^{\circ} \mathrm{C}$ for $30 \mathrm{~s}$ and the melting curve was measured continuously by fluorescence. $\beta$-Actin was always amplified in parallel with the target gene as a control. The cDNA from each sample was subjected to qRT-PCR using the primer pairs listed in Table 1. Expression levels were determined using the relative threshold cycle (CT) method as described by the manufacturer.

\subsection{Western blot analysis}

IEC-6 cell proteins were extracted with a total protein extraction kit (Biochain, Hayward, CA, USA) and quantified with the BCA protein assay kit (Pierce, Rockford, IL, USA). Proteins were resolved on $8 \%-12 \%(\mathrm{w} / \mathrm{v})$ sodium dodecyl sulfate polyacrylamide gel electrophoresis (SDS-PAGE) and transferred onto a nitrocellulose membrane (Pierce, Rockford, USA). Membranes were blocked for $2.5 \mathrm{~h}$ at room temperature using SuperBlock T20 (TBS) blocking buffer (Pierce). Primary antibodies (1:1000, v/v) were rabbit sources: p21 (Abcam, Cambridge, UK), p27 (Abcam), pRb (Cell Signaling Technology, Boston, MA, USA), E2F1 (Abcam), CDK4 (Abcam),

Table 1 Primers for real-time PCR

\begin{tabular}{|c|c|c|}
\hline Description & Accession number & Primer sequence $\left(5^{\prime} \rightarrow 3^{\prime}\right)$ \\
\hline \multirow[t]{2}{*}{$\beta$-Actin } & NM_031144 & Forward: TTGTCCCTGTATGCCTCTGG \\
\hline & & Reverse: ATGTCACGCACGATTTCCC \\
\hline \multirow[t]{2}{*}{ p21 } & NM_080782.3 & Forward: AGTATGCCGTCGTCTGTTCG \\
\hline & & Reverse: TCAAAGTTCCACCGTTCTCG \\
\hline \multirow[t]{2}{*}{ p27 } & NM_031762.3 & Forward: GCTTGCCCGAGTTCTACTACAG \\
\hline & & Reverse: AGAGTTTGCCTGAGACCCAAT \\
\hline \multirow[t]{2}{*}{$\mathrm{Rb}$} & NM_017045 & Forward: CTGCTCAGAGAGCCGTACAAA \\
\hline & & Reverse: CGAGCACTCCTGTTCTGACC \\
\hline \multirow[t]{2}{*}{ Cyclin D1 } & NM_171992.4 & Forward: ACCTGGACCGTTTCTTGTCTC \\
\hline & & Reverse: GGCGGATAGAGTTGTCAGTGT \\
\hline \multirow[t]{2}{*}{ CDK4 } & NM_053593 & Forward: AGATCCCCTGCTCCGAGAAT \\
\hline & & Reverse: ACATCCATCAGCCGTACAACAT \\
\hline \multirow[t]{2}{*}{ E2F1 } & NM_001100778 & Forward: GCTCCACTGCCCTTCCCACT \\
\hline & & Reverse: CCCAACCCAGCCTAACACCA \\
\hline
\end{tabular}


cyclin D1 (Cell Signaling Technology), and $\beta$-actin (Cell Signaling Technology); membranes were incubated for $4 \mathrm{~h}$ or overnight with the primary antibodies. The secondary antibody was donkey antirabbit (Cell Signaling Technology) at a dilution of 1:15000, and membranes were incubated with the secondary antibodies for $1 \mathrm{~h}$. The antigens were then visualized and analyzed with the Odyssey infrared imaging system (LI-COR Biosciences, Lincoln, NE, USA). $\beta$-Actin was used as a loading control. The relative density of protein bands in each blot was measured using the ImageJ program (National Institutes of Health, Bethesda, MD, USA).

\subsection{Statistical analysis}

SPSS 11.5 (Softonic, Barcelona, Spain) was used for statistical analysis. Data were analyzed by a $t$-test when there were only two groups of data. If there were three or more groups, data were analyzed by one-way analysis of variance (ANOVA). $P<0.05$ was regarded as a significant difference.

\section{Results}

\subsection{Cytotoxicity by Mag}

To determine Mag-induced toxicity on IEC-6 cells by MTS cell proliferation assay, we treated the cells with various concentrations of Mag (10 to $500 \mu \mathrm{mol} / \mathrm{L}$ ) for 24,48 , and $72 \mathrm{~h}$. As shown in Fig. 2, Mag concentrations under $100 \mu \mathrm{mol} / \mathrm{L}$ were not toxic for IEC-6 cells. However, exposure of cells to Mag at $200 \mu \mathrm{mol} / \mathrm{L}$ for 24,48 , or $72 \mathrm{~h}$ resulted in significant inhibition of proliferation $(P<0.01)$. This indicated that, when Mag concentration reached $200 \mu \mathrm{mol} / \mathrm{L}$, it caused toxicity in IEC- 6 cells. Pre-exposure of cells to $20 \mu \mathrm{mol} / \mathrm{L}$ Mag for $3 \mathrm{~h}$ and HS for another $3 \mathrm{~h}$ resulted in a significant increase in cell number as compared with those in the group receiving HS only (Fig. 3).

\subsection{Mag decreased IEC-6 cell drifting and injury condition}

As shown in Fig. 4, hemocytometer cell counts in the HS group were about one-fifth of those in the control group $(P<0.05)$. Pretreatment with $\operatorname{Mag}(5,10$, or $20 \mu \mathrm{mol} / \mathrm{L}$ ) prior to HS resulted in significant prevention of cell shape changes $(P<0.05)$ as compared with the group receiving only HS. The effect of
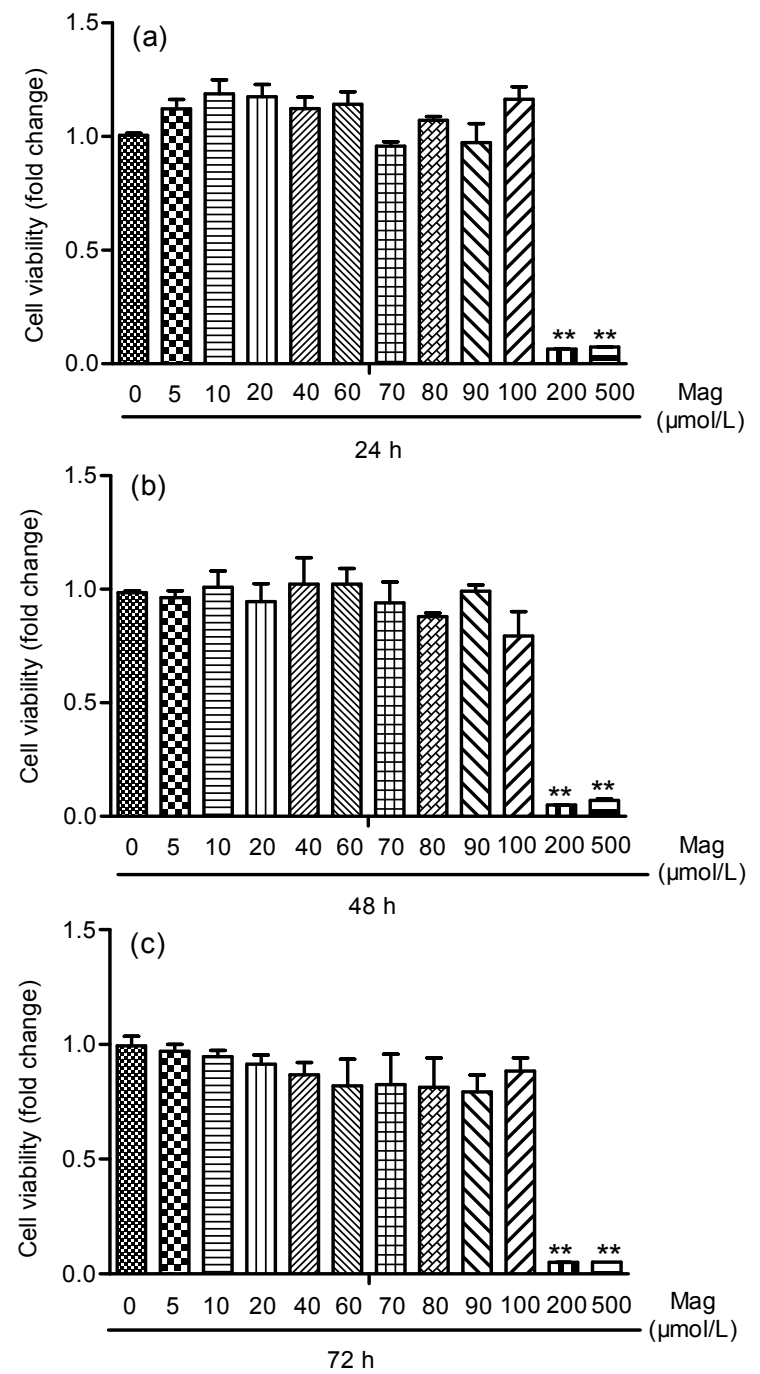

Fig. 2 Mag toxicity in IEC-6 cells by MTS cell proliferation assay

IEC-6 cells were treated with Mag for 24 (a), 48 (b), and $72 \mathrm{~h}$ (c). Results shown are representative of three independent experiments. ${ }^{* *} P<0.01$ compared with the control group

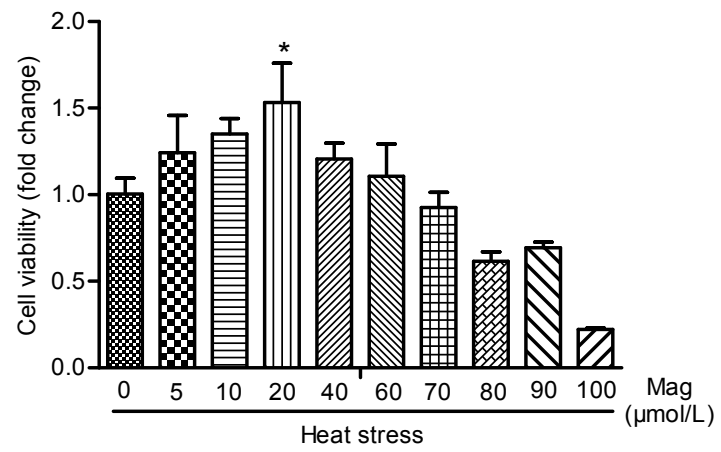

Fig. 3 Comparing three effective concentrations $(5,10$, and $20 \mu \mathrm{mol} / \mathrm{L}$ ) of Mag by MTS cell proliferation assay Mag at $20 \mu \mathrm{mol} / \mathrm{L}$ showed significant anti-HS effects $\left({ }^{*} P<0.05\right)$. Results (mean \pm SEM) shown are representative of three independent experiments 
Mag was dose-dependent. The cell number in cultures treated with $20 \mu \mathrm{mol} / \mathrm{L} \mathrm{Mag}$ was close to that in the control group. LDH release is an indicator of cell injury. As shown in Fig. 5, compared with the control group (14 times), IEC-6 cells showed markedly greater LDH release in the HS group, almost 54 times $(P<0.01)$; Mag efficiently suppressed LDH release by IEC- 6 cells to almost 50 times $(5 \mu \mathrm{mol} / \mathrm{L} ; P>0.05)$, 44 times $(10 \mu \mathrm{mol} / \mathrm{L} ; P<0.05)$, and 43 times (20 $\mu \mathrm{mol} / \mathrm{L} ; P<0.01$ ), respectively. Furthermore, these results suggested that Mag increased cell viability and decreased cell injury in a dose-dependent manner.

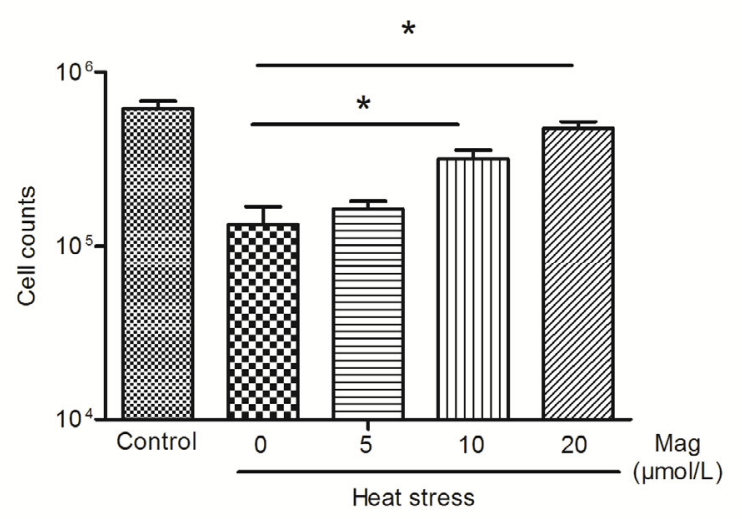

Fig. 4 Cell counts after HS by hemocytometer IEC-6 cells were treated with HS alone or HS after pretreatment with various concentrations of $\operatorname{Mag}(5,10$, and $20 \mu \mathrm{mol} / \mathrm{L})$. At 10 and $20 \mu \mathrm{mol} / \mathrm{L}$, Mag markedly increased cell counts as compared with those in the group receiving only HS $\left({ }^{*} P<0.05\right)$. Results (mean \pm SEM) shown are representative of three independent experiments

\subsection{Mag prevented HS-induced G1-phase cell- cycle arrest}

As Mag reduced IEC-6 cell rounding, we next investigated whether effects of Mag were associated with cell-cycle progression. Cell-cycle effects on IEC-6 cells subjected to HS were, however, little known. The percentage of cells at each phase of the cell cycle was examined by flow cytometry. The cell-cycle response was determined in the cells treated with various concentrations $(5,10$, or $20 \mu \mathrm{mol} / \mathrm{L})$ of Mag for $3 \mathrm{~h}$ prior to HS. As shown in Fig. 6, cell-cycle analysis revealed that HS induced G1-phase cellcycle arrest (about 96.5\%) as compared with that in

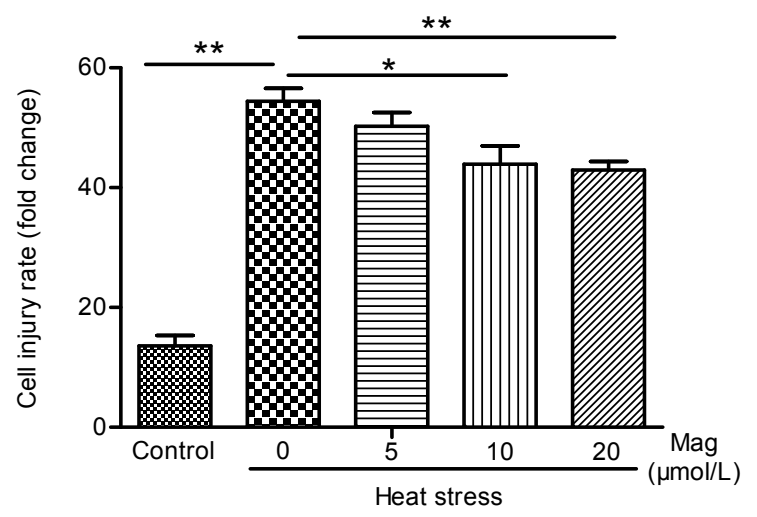

Fig. 5 Lactate dehydrogenase activity in IEC-6 cells IEC-6 cells were treated with HS alone or after pretreatment with various concentrations of $\operatorname{Mag}(5,10$, and $20 \mu \mathrm{mol} / \mathrm{L})$ before HS. Mag pretreatment decreased LDH activity as compared with the HS group $\left({ }^{*} P<0.05,{ }^{* *} P<0.01\right)$. Results (mean \pm SEM) shown are representative of three independent experiments

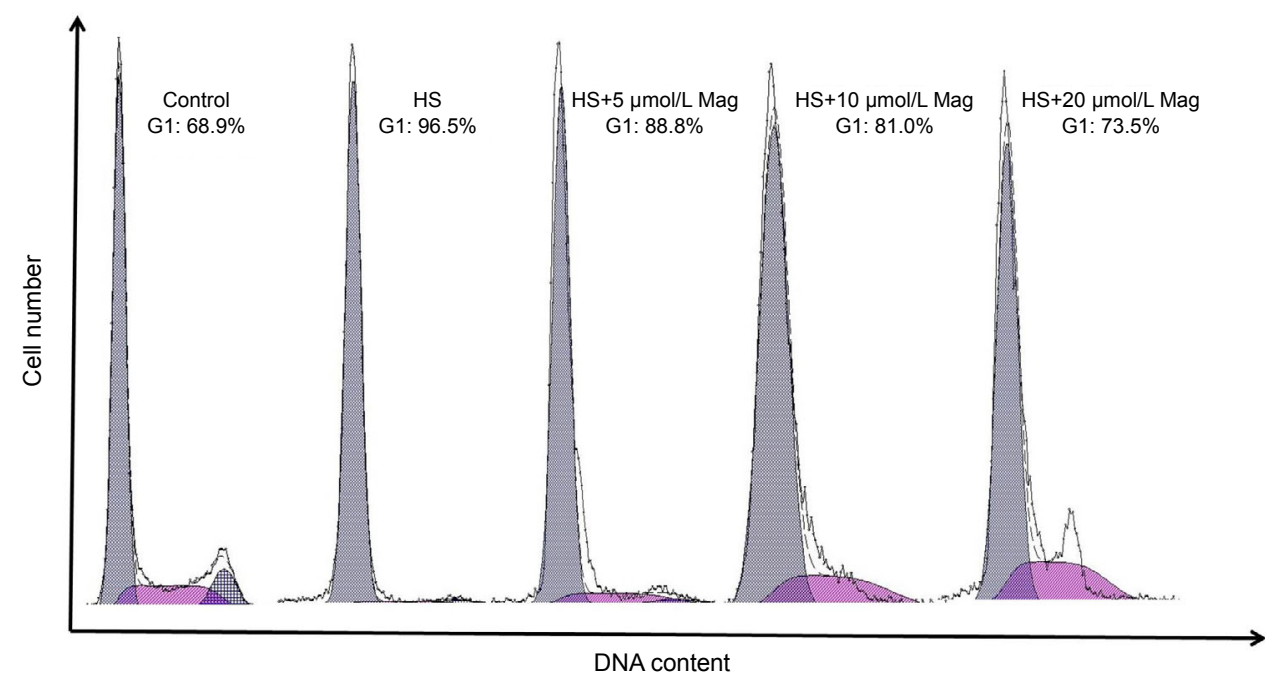

Fig. 6 Mag-corrected cell-cycle progression in IEC-6 cells after HS

Groups are: control, HS, and HS after Mag pretreatment at three concentrations $(5,10$, and $20 \mu \mathrm{mol} / \mathrm{L})$ 
the control cells $(68.9 \%)$. Pretreatment with Mag resulted in a dose-dependent reduction of cell-cycle arrest after HS. G1-phase cell-cycle arrest was $88.8 \%$, $81.0 \%$, and $73.5 \%$ in cells treated with 5,10 , and $20 \mu \mathrm{mol} / \mathrm{L} \mathrm{Mag}$, respectively.

\subsection{Mag accelerated IEC-6 cell division after HS}

As anticipated, cells in the HS group (Fig. 7b) showed little cell division as compared with the control group (Fig. 7a). After pretreatment, before HS, with 5 (Fig. 7c), 10 (Fig. 7d), or $20 \mu \mathrm{mol} / \mathrm{L}$ Mag (Fig. 7e), numbers of splinter cells gradually increased. We conclude that Mag at least partly suppressed injury of IEC-6 cells after HS.

\subsection{Effect of Mag on cell-cycle gene progression of IEC-6 cells}

After finding that Mag promoted IEC-6 cell viability, we were interested in the underlying mechanisms of this effect. $p 21$ (Fig. 8a), p27 (Fig. 8b), and $R b$ (Fig. 8c) are important genes suppressing the cell cycle. PCR results showed that these three genes had elevated expression in the HS group as compared with the expression levels in the control group. Cells pretreated with $\operatorname{Mag}(5,10$, or $20 \mu \mathrm{mol} / \mathrm{L})$ for $3 \mathrm{~h}$ before HS showed a dose-dependent reduction of expression of these three genes $(P<0.05$ or $P<0.01)$. E2F1 (Fig. 8d), CDK4 (Fig. 8e), and cyclin D1 (Fig. 8f) are genes that promote the cell cycle. These genes showed

(a) Control

EdU

Hoechst

Overlay

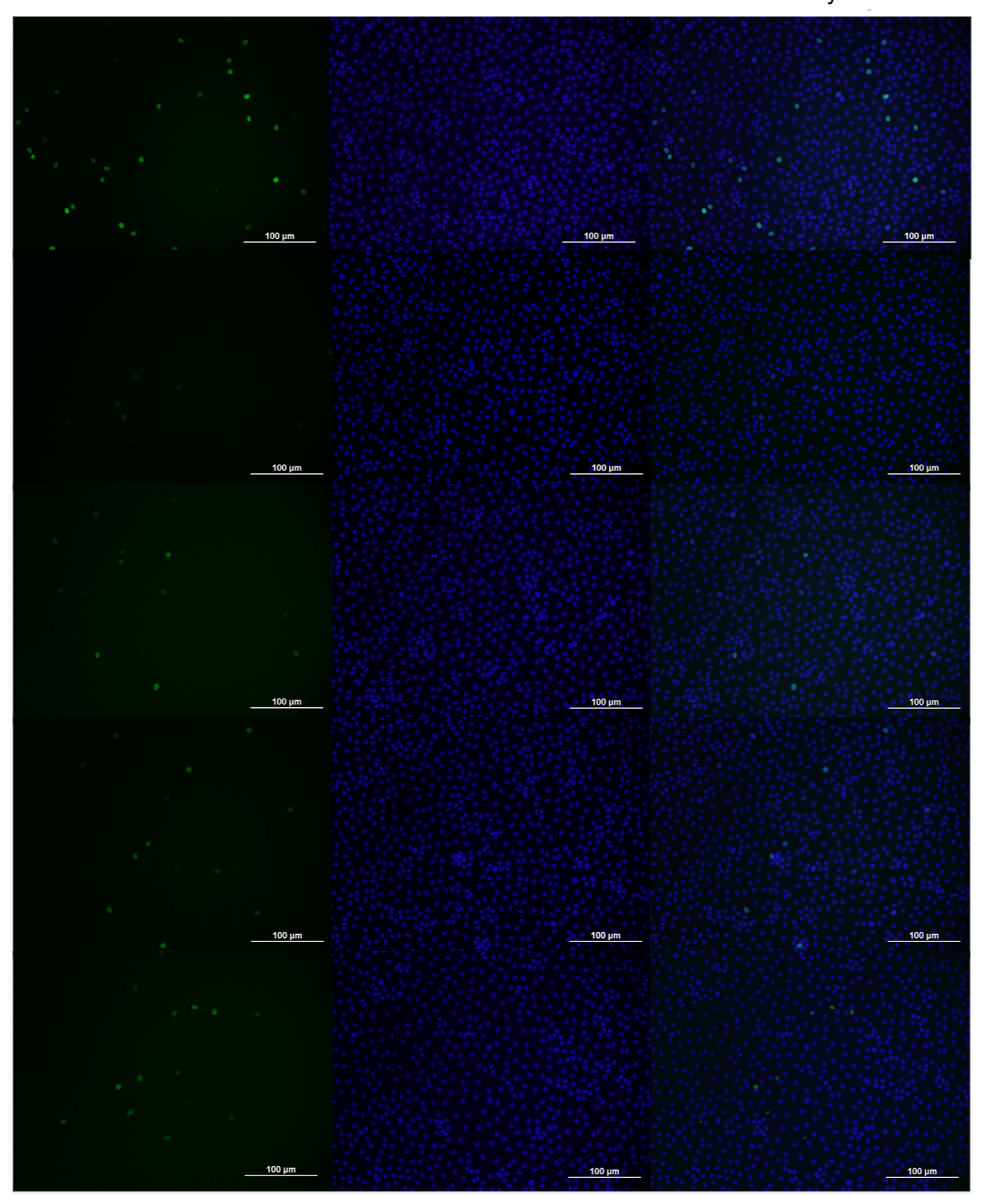

Fig. 7 Mag increases IEC-6 cell division based on EdU incorporation

Control group (a), HS group (b), groups pretreated with Mag $(5,10$, or $20 \mu \mathrm{mol} / \mathrm{L})(\mathrm{c}-\mathrm{e})$ prior to HS. Cells in left, middle, and right figures were marked by EdU, Hoechst stain, and Overlay, respectively. Results shown are representative of three independent experiments. Bar $=100 \mu \mathrm{m}$ 

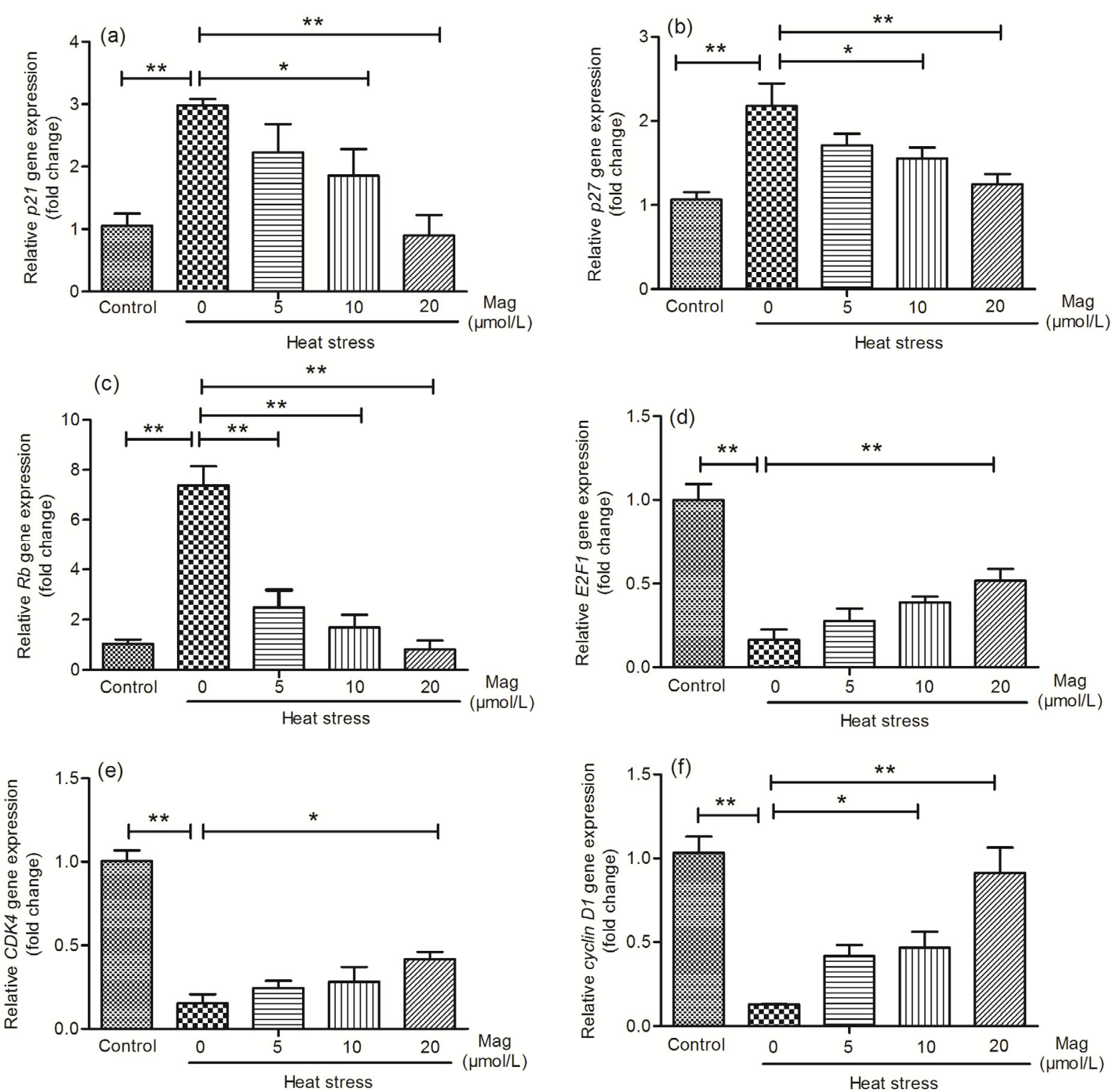

Fig. 8 Mag modulates levels of G1-phase cell-cycle genes in IEC-6 cells

Results (mean $\pm \mathrm{SEM}$ ) shown are representative of three independent experiments. As compared with HS alone, Mag pretreatment before HS caused dose-dependent changes in gene expression of $p 21$ (a), p27 (b), Rb (c), E2F1 (d), CDK4 (e), and cyclin D1 (f). All these genes showed significant differences between the HS group and Mag groups ( $\left.{ }^{*} P<0.05,{ }^{* *} P<0.01\right)$

markedly decreased expression in the HS group as compared with the control group. Mag pretreatment effectively up-regulated their expression in a dosedependent manner $(P<0.05$ or $P<0.01)$.

\subsection{Mag promotes G1-phase cell-cycle resumption after HS}

Based on the qRT-PCR data, we examined expression of G1-phase proteins (Fig. 9). Western blot analysis revealed that the levels of the cell-cycle inhibition proteins p21 (Fig. 9a) and p27 (Fig. 9b) increased after HS, but decreased after pretreatment with Mag, especially at $20 \mu \mathrm{mol} / \mathrm{L}$. On further examination of the levels of G1-phase cell-cycle proteins after HS, we found that E2F1 (Fig. 9d), pRb (Fig. 9c), cyclin D1 (CCND1) (Fig. 9f), and CDK4 (Fig. 9e) were down-regulated by HS and that Mag pretreatment increased their expression. We conclude that Mag reduced cell injury partly by suppressing HS-induced G1-phase cell-cycle arrest. 

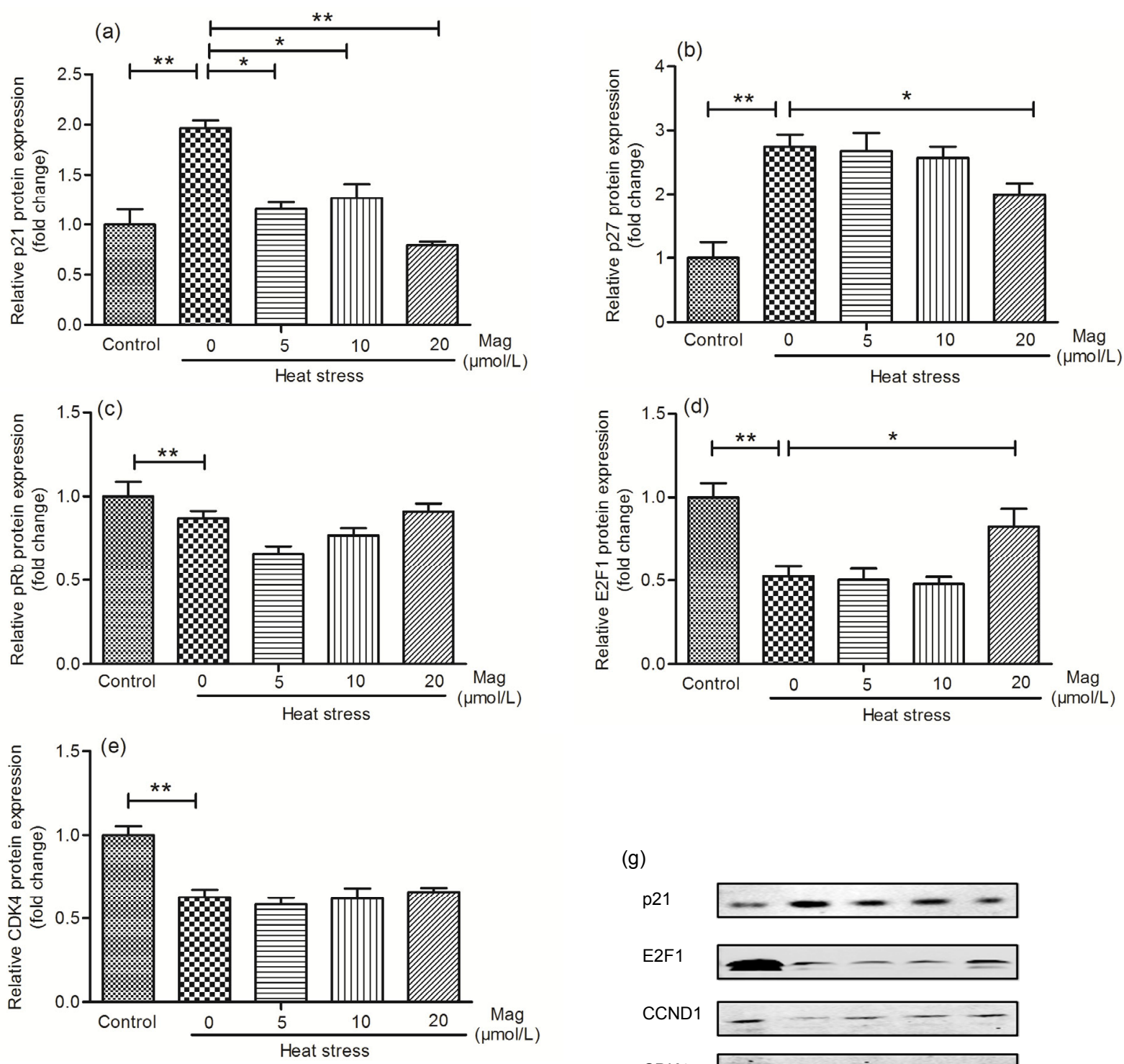

(g)

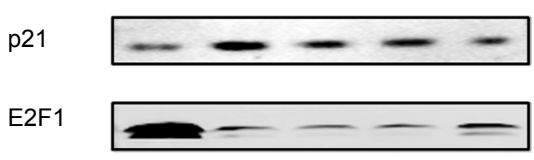

CCND1

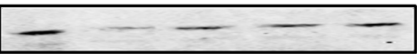

CDK4
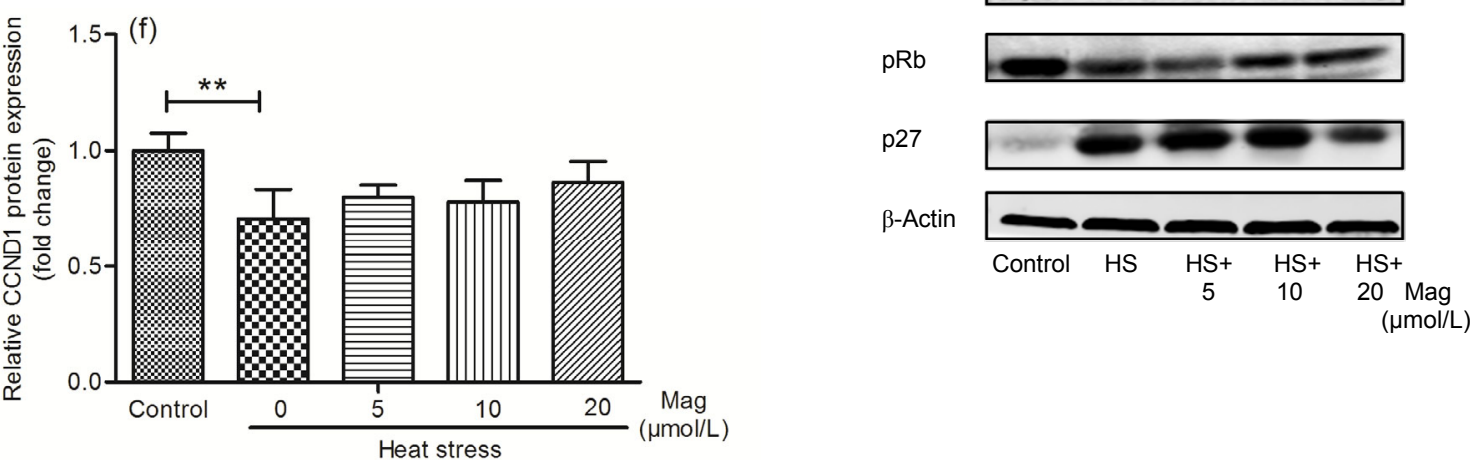

Fig. 9 Mag induces G1-phase cell-cycle restoration after HS

Treated groups were: control, HS, and HS pretreated with Mag $(5,10$, or $20 \mu \mathrm{mol} / \mathrm{L}$ ). Results (mean $\pm \mathrm{SEM}$ ) shown are representative of three independent experiments. Immunoblot analysis was performed to detect the expression of the G1-phase proteins expression (g). Proteins were p21 (a), p27 (b), pRb (c), E2F1 (d), CDK4 (e), and CCND1 (f). Differences between mean values were assessed by one-way ANOVA $\left({ }^{*} P<0.05,{ }^{* *} P<0.01\right)$ 


\section{Discussion}

It is established that elevated ambient temperatures induce a series of physiological changes in biological organisms (Intasqui et al., 2015; Khosravinia, 2015). These findings indicate that understanding the mechanisms of HS-induced injury in animals is extremely urgent. More effective measures are greatly needed to reduce the adverse effects of HS. In our study, IEC-6 cells exposed to HS underwent a sharply reduction in cell number compared with the control group. These observations agree with previous reports (Miova et al., 2015).

Mag is extracted from magnolia and is a natural compound with many pharmacological activities. It has been reported that it has protective effects on the small intestine (Loong et al., 2002) and anti-HS functions (Chang et al., 2003). Our study showed that Mag showed a non-toxic function under $100 \mu \mathrm{mol} / \mathrm{L}$. When pretreating with Mag before HS, Mag has a protective effect on increased cell vitality, reducing cell floating, stimulating cell adhesion, and promoting cell proliferation.

The cell cycle is a fundamental process of cellular function. HS is known to significantly influence the cell-cycle program with hyperthermia. HS induced apoptosis by G2/M phase arrest (Qi et al., 2015) and affected expression of genes, especially cyclin $D 1$ and $p 21$, that regulate the G1-phase cell-cycle program (Kaija et al., 2015). However, there have been no reports describing whether HS influences the IEC- 6 cell cycle. In our study, the percentage of cells in the G1 phase decreased from $96.5 \%$ in the HS group to $88.8 \%, 81.0 \%$, and $73.5 \%$ in cells pretreated with 5,10 , and $20 \mu \mathrm{mol} / \mathrm{L}$ of Mag, respectively, prior to HS. The EdU incorporation assay showed a dosedependent increase in the number of dividing cells with Mag. With $20 \mu \mathrm{mol} / \mathrm{L}$ Mag, effective cell proliferation occurred after HS. Taking all of our data together, it can be seen more clearly that Mag decreases cell injury induced by HS.

Over recent years, the accumulated data indicate that HS induces cell-cycle arrest and impairs normal cell growth (de Maria et al., 2013; Alekseenko et al., 2014; Sarkar et al., 2014). The cell cycle is very complex, and a number of key factors are involved in its regulation. Therefore, we investigated effects on several of these factors by examining gene expression and protein levels in IEC-6 cells after exposure to HS. Cyclin D1 is one of the important factors in cell-cycle regulation, primarily controlling G1-to-S phase transition (Wu et al., 2009). After HS, expression of cyclin D1, at both gene and protein levels, significantly decreased. This proved that cyclin D1 expression was negatively correlated with cell-cycle arrest and that Mag could up-regulate cyclin D1 after HS, enabling recovery and normal operation of the cell cycle. CDK4 as a co-bonding molecule showed the same trend in expression as cyclin D1. The effects of Mag on levels of these proteins indicated that this agent participated in reducing G1 cell-cycle arrest (Adnane et al., 1999; McMahon et al., 1999; Coqueret, 2002). As an important cell-cycle control factor, E2F1 works, along with $\mathrm{Rb}$, to regulate the transition from $\mathrm{G} 0 / \mathrm{G} 1$ to $\mathrm{S}$ phase (Fofaria et al., 2014). In this study, E2F1 expression was significantly down-regulated by HS, further illustrating that HS induced cell-cycle arrest. Mag pretreatment led to partial recovery of the E2F1 expression level, suggesting that Mag exerted a protective role at the execution phase of G1-phase cellcycle arrest. $\mathrm{Rb}$ negatively regulates the cell cycle by inhibiting cell proliferation. When $\mathrm{Rb}$ is phosphorylated by cyclin-CDK, E2Fs are released to promote cell proliferation. Dephosphorylated Rb works with E2F1 to control the latter from entering the nucleus to activate gene expression, controlling transition from the G1 to the S phase (Kuhl and Rensing, 2000). Our results indicate that expression of the $R b$ gene was high but that the $\mathrm{pRb}$ protein was down-regulated after HS. This provided further evidence that HS induced G1 cell-cycle arrest. Mag partly prevented HS-induced cell-cycle arrest through adjusting $\mathrm{Rb}$ and $\mathrm{pRb}$ ratios nearer to those in the control cells. p21 inhibits G1-phase cyclin-cyclin-dependent protein kinase (CDK) activity by changing the configuration of CDK (Mitrea et al., 2012). Recent studies have shown that $\mathrm{p} 21$ in many cell lines functions to inhibit cell proliferation, such as in liver cancer (Bang et al., 2015), gastric carcinoma (Gao et al., 2014), breast cancer (Yan et al., 2015), and lung cancer (Men et al., 2015). $\mathrm{p} 27$ is one of the CDK inhibitor (CDKI) factors, which inhibits cell proliferation and induces cell differentiation. p27 is believed to inhibit CDK activity by combining with CDK or cyclin-CDK compounds (Zhang Y. et al., 2015). Our data showed that p21 and p27 were significantly higher in the HS 
group than in the control group, indicating that $\mathrm{p} 21$ and p27 were involved in the cell-cycle arrest. Mag effectively down-regulated $\mathrm{p} 21$ and $\mathrm{p} 27$ expressions, suggesting that the agent can adjust expressions of cell-cycle inhibitors to prevent cell-cycle arrest. Our data indicate that HS induced both cell injury and G1-phase cell-cycle arrest. Mag exhibited its anti-HS effect partly through preventing cell-cycle arrest by p21, p27, pRb, E2F1, CDK4, and cyclin D1. Others have shown that Mag, instead, induced cell-cycle arrest (Rasul et al., 2012). There are a number of possible reasons for this inconsistency. First, we used a rat intestinal epithelial cell line, unlike the SGC7901 human gastric adenocarcinoma cells used in other studies. Second, Mag in different concentration ranges showed different effects on the cells. In our experiment, Mag at low doses $(5,10$, and $20 \mu \mathrm{mol} / \mathrm{L})$ revealed anti-HS effects and prevention of cell-cycle arrest. Results were different with higher doses of Mag $(40,60$, and $80 \mu \mathrm{mol} / \mathrm{L})$, and these higher doses have been used to treat cancer in other studies. Therefore, our results are not contradictory.

In conclusion, HS induced IEC- 6 cell injury and G1-phase cell-cycle arrest involving control by p21, p27, Rb, E2F1, cyclin D1, and CDK4. Mag is a promising natural compound for the treatment of HS, and its effects may be due to the suppression of HSinduced cell-cycle arrest to prevent injury to IEC-6 cells. These data provide the foundation for further research to develop anti-HS medicines in IEC-6 cells and other animals.

\section{Compliance with ethics guidelines}

Chen MEI, Sha-sha HE, Peng YIN, Lei XU, Ya-ran SHI, Xiao-hong YU, An LYU, Feng-hua LIU, and Lin-shu JIANG declare that they have no conflict of interest.

This article does not contain any studies with human or animal subjects performed by any of the authors.

\section{References}

Adnane, J., Shao, Z., Robbins, P.D., 1999. Cyclin D1 associates with the TBP-associated factor $\mathrm{TAF}_{\mathrm{II}} 250$ to regulate $\mathrm{Sp} 1$ mediated transcription. Oncogene, 18(1):239-247. http://dx.doi.org/10.1038/sj.onc.1202297

Alekseenko, L.L., Zemelko, V.I., Domnina, A.P., et al., 2014. Sublethal heat shock induces premature senescence rather than apoptosis in human mesenchymal stem cells. Cell Stress Chaperon., 19(3):355-366. http://dx.doi.org/10.1007/s12192-013-0463-6

Bang, J., Huh, J.H., Na, J.W., et al., 2015. Cell proliferation and motility are inhibited by G1 phase arrest in $15-\mathrm{kDa}$ selenoprotein-deficient Chang liver cells. Mol. Cells, 38(5):457-465.

http://dx.doi.org/10.14348/molcells.2015.0007

Chang, C.P., Hsu, Y.C., Lin, M.T., 2003. Magnolol protects against cerebral ischaemic injury of rat heatstroke. Clin. Exp. Pharmacol. Physiol., 30(5-6):387-392. http://dx.doi.org/10.1046/j.1440-1681.2003.03847.x

Chen, S.C., Chang, Y.L., Wang, D.L., et al., 2006. Herbal remedy magnolol suppresses IL-6-induced STAT3 activation and gene expression in endothelial cells. $\mathrm{Br}$. $J$. Pharmacol., 148(2):226-232. http://dx.doi.org/10.1038/sj.bjp.0706647

Coqueret, O., 2002. Linking cyclins to transcriptional control. Gene, 299(1-2):35-55. http://dx.doi.org/10.1016/S0378-1119(02)01055-7

de Maria, S., Scognamiglio, I., Lombardi, A., et al., 2013. Polydatin, a natural precursor of resveratrol, induces cell cycle arrest and differentiation of human colorectal Caco-2 cell. J. Transl. Med., 11(1):264. http://dx.doi.org/10.1186/1479-5876-11-264

Fofaria, N.M., Kim, S.H., Srivastava, S.K., 2014. Piperine causes G1 phase cell cycle arrest and apoptosis in melanoma cells through checkpoint kinase-1 activation. PLoS ONE, 9(5):e94298. http://dx.doi.org/10.1371/journal.pone.0094298

Gao, C.C., Ma, T.H., Pang, L.Q., et al., 2014. Activation of p21-activated protein kinase 2 is an independent prognostic predictor for patients with gastric cancer. Diagn. Pathol., 9(1):55.

http://dx.doi.org/10.1186/1746-1596-9-55

Gao, C.Q., Zhao, Y.L., Li, H.C., et al., 2015. Heat stress inhibits proliferation, promotes growth, and induces apoptosis in cultured Lantang swine skeletal muscle satellite cells. J. Zhejiang Univ.-Sci. B (Biomed. \& Biotechnol.), 16(6):549-559. http://dx.doi.org/10.1631/jzus.B1400339

Guerra-Araiza, C., Alvarez-Mejia, A.L., Sanchez-Torres, S., et al., 2013. Effect of natural exogenous antioxidants on aging and on neurodegenerative diseases. Free Radic. Res., 47(6-7):451-462. http://dx.doi.org/10.3109/10715762.2013.795649

Guyot, S., Gervais, P., Young, M., et al., 2015. Surviving the heat: heterogeneity of response in Saccharomyces cerevisiae provides insight into thermal damage to the membrane. Environ. Microbiol., 17(8):2982-2992. http://dx.doi.org/10.1111/1462-2920.12866

Intasqui, P., Antoniassi, M.P., Camargo, M., et al., 2015. Differences in the seminal plasma proteome are associated with oxidative stress levels in men with normal semen parameters. Fertil. Steril., 104(2):292-301. http://dx.doi.org/10.1016/j.fertnstert.2015.04.037

Kaija, H., Pakanen, L., Kortelainen, M.L., et al., 2015. Hypothermia and rewarming induce gene expression and multiplication of cells in healthy rat prostate tissue. $P L O S$ ONE, 10(5): 0127854.

http://dx.doi.org/10.1371/journal.pone.0127854

Khosravinia, H., 2015. Effects of Satureja khuzistanica 
essential oils in drinking water on mortality, production performance, water intake, and organ weights in broiler chickens reared under heat stress condition. Int. J. Biometeorol., 59(11):1711-1719. http://dx.doi.org/10.1007/s00484-015-0979-9

Kong, C.W., Tsai, K., Chin, J.H., et al., 2000. Magnolol attenuates peroxidative damage and improves survival of rats with sepsis. Shock, 13(1):24-28. http://dx.doi.org/10.1097/00024382-200013010-00005

Kuhl, N.M., Rensing, L., 2000. Heat shock effects on cell cycle progression. Cell Mol. Life Sci., 57(3):450-463. http://dx.doi.org/10.1007/PL00000707

Lee, K.L., Niu, K.C., Lin, M.T., et al., 2013. Attenuating brain inflammation, ischemia, and oxidative damage by hyperbaric oxygen in diabetic rats after heat stroke. $J$. Formos. Med. Assoc., 112(8):454-462. http://dx.doi.org/10.1016/j.jfma.2012.02.017

Lei, L., Hepeng, L., Xianlei, L., et al., 2013. Effects of acute heat stress on gene expression of brain-gut neuropeptides in broiler chickens. J. Anim. Sci., 91(11):5194-5201. http://dx.doi.org/10.2527/jas.2013-6538

Loong, C.C., Chiu, J.H., Tiao, R.C., et al., 2002. Protective effect of magnolol on the small intestinal ischemiareperfusion injury. Transplant. Proc., 34(7):2679-2680. http://dx.doi.org/10.1016/S0041-1345(02)03373-0

McMahon, C., Suthiphongchai, T., Direnzo, J., et al., 1999. $\mathrm{P} / \mathrm{CAF}$ associates with cyclin D1 and potentiates its activation of the estrogen receptor. PNAS, 96(10):53825387. http://dx.doi.org/10.1073/pnas.96.10.5382

Men, X., Wang, L., Yu, W., et al., 2015. Cullin7 is required for lung cancer cell proliferation and is overexpressed in lung cancer. Oncol. Res., 22(2):123-128. http://dx.doi.org/10.3727/096504014X14198596979742

Min, L., Cheng, J.B., Shi, B.L., et al., 2015. Effects of heat stress on serum insulin, adipokines, AMP-activated protein kinase, and heat shock signal molecules in dairy cows. J. Zhejiang Univ.-Sci. B (Biomed. \& Biotechnol.), 16(6):541-548. http://dx.doi.org/10.1631/jzus.B1400341

Miova, B., Dinevska-Kjovkarovska, S., Esplugues, J.V., et al., 2015. Heat stress induces extended plateau of Hsp70 accumulation - a possible cytoprotection mechanism in hepatic cells. J. Cell. Biochem., 116(10):2365-2374. http://dx.doi.org/10.1002/jcb.25187

Mitrea, D.M., Yoon, M.K., Ou, L., et al., 2012. Disorderfunction relationships for the cell cycle regulatory proteins p21 and p27. Biol. Chem., 393(4):259-274. http://dx.doi.org/10.1515/hsz-2011-0254

Pan, Z., Shao, Y., Dong, W., et al., 2014. Xuebijing attenuates hypotension through the upregulation of angiotensin II type 1 receptor-associated protein 1 in rats suffering from heat stroke. Int. J. Mol. Med., 34(6):1699-1705. http://dx.doi.org/10.3892/ijmm.2014.1950

Qi, D., Hu, Y., Li, J., et al., 2015. Hyperthermia induces apoptosis of 786-O cells through suppressing $\mathrm{Ku} 80$ expression. PLoS ONE, 10(4):e0122977.

http://dx.doi.org/10.1371/journal.pone.0122977

Rasul, A., Yu, B., Khan, M., et al., 2012. Magnolol, a natural compound, induces apoptosis of SGC-7901 human gastric adenocarcinoma cells via the mitochondrial and PI3K/AKT signaling pathways. Int. J. Oncol., 40(4): 1153-1161. http://dx.doi.org/10.3892/ijo.2011.1277

Sarkar, R., Mukherjee, A., Mukherjee, S., et al., 2014. Curcumin augments the efficacy of antitumor drugs used in leukemia by modulation of heat shock proteins via HDAC6. J. Environ. Pathol. Toxicol. Oncol., 33(3):247-263. http://dx.doi.org/10.1615/JEnvironPatholToxicolOncol.2 014010913

Song, X., Luo, J., Fu, D., et al., 2014. Traditional Chinese medicine prescriptions enhance growth performance of heat stressed beef cattle by relieving heat stress responses and increasing apparent nutrient digestibility. AsianAustralas J. Anim. Sci., 27(10):1513-1520. http://dx.doi.org/10.5713/ajas.2014.14058

Song, Z., Liu, L., Sheikhahmadi, A., et al., 2012. Effect of heat exposure on gene expression of feed intake regulatory peptides in laying hens. J. Biomed. Biotechnol., 2012: 484869. http://dx.doi.org/10.1155/2012/484869

Sun, E.L., Wei, W.J., Wang, L.N., et al., 2015. Musashi-1 maintains blood-testis barrier structure during spermatogenesis and regulates stress granule formation upon heat stress. Mol. Biol. Cell, 26(10):1947-1956. http://dx.doi.org/10.1091/mbc.E14-11-1497

Wang, W., Liang, D.J., Song, X.J., et al., 2015. Magnolol inhibits the inflammatory response in mouse mammary epithelial cells and a mouse mastitis model. Inflammation, 38(1):16-26. http://dx.doi.org/10.1007/s10753-014-0003-2

Wu, C.L., Wang, H.Y., Xu, J., et al., 2014. Magnolol inhibits tumor necrosis factor- $\alpha$-induced ICAM- 1 expression via suppressing NF- $\kappa B$ and MAPK signaling pathways in human lung epithelial cells. Inflammation, 37(6):19571967.

http://dx.doi.org/10.1007/s10753-014-9928-8

$\mathrm{Wu}$, J., Wu, S.H., Bollig, A., et al., 2009. Identification of the cyclin D1b mRNA variant in mouse. Mol. Biol. Rep., 36(5):953-957. http://dx.doi.org/10.1007/s11033-008-9267-7

Xia, X., Wang, H., Niu, X., et al., 2014. Assessment of the anti-diarrhea function of compound Chinese herbal medicine cangpo oral liquid. Afr. J. Tradit. Complement. Altern. Med., 11(1):140-147. http://dx.doi.org/10.4314/ajtcam.v11i1.22

Yan, J., Liu, X.L., Han, L.Z., et al., 2015. Relation between Ki-67, ER, PR, Her2/neu, p21, EGFR, and TOP II- $\alpha$ expression in invasive ductal breast cancer patients and correlations with prognosis. Asian Pac. J. Cancer Prev., 16(2):823-829. http://dx.doi.org/10.7314/APJCP.2015.16.2.823 
Yin, J., Liu, M., Ren, W., et al., 2015a. Effects of dietary supplementation with glutamate and aspartate on diquatinduced oxidative stress in piglets. PLOS ONE, 10(4): e0122893.

http://dx.doi.org/10.1371/journal.pone.0122893

Yin, J., Ren, W., Yang, G., et al., 2015b. L-Cysteine metabolism and its nutritional implications. Mol. Nutr. Food Res., 60(1):134-146.

http://dx.doi.org/10.1002/mnfr.201500031

Yin, J., Wu, M., Duan, J., et al., 2015c. Pyrrolidine dithiocarbamate inhibits NF- $\mathrm{B}$ activation and upregulates the expression of Gpx1, Gpx4, occludin, and ZO-1 in DSS-induced colitis. Appl. Biochem. Biotechnol., 177(8): 1716-1728. http://dx.doi.org/10.1007/s12010-015-1848-Z

Yu, J., Yin, P., Yin, J., et al., 2010. Involvement of ERK1/2 signalling and growth-related molecules' expression in response to heat stress-induced damage in rat jejunum and IEC-6 cells. Int. J. Hyperther., 26(6):538-555. http://dx.doi.org/10.3109/02656736.2010.481276

Zhang, M.H., Shi, Z.D., Yu, J.C., et al., 2015. Scrotal heat stress causes sperm chromatin damage and cysteinyl aspartate-spicific proteinases 3 changes in fertile men. $J$. Assist. Reprod. Genet., 32(5):747-755. http://dx.doi.org/10.1007/s10815-015-0451-0

Zhang, Y., Zhou, Z.W., Jin, H., et al., 2015. Schisandrin B inhibits cell growth and induces cellular apoptosis and autophagy in mouse hepatocytes and macrophages: implications for its hepatotoxicity. Drug Des. Dev. Ther., 9:2001-2027.

http://dx.doi.org/10.2147/dddt.s77071

\section{中文概要}

题 目: 厚朴酚缓解热应激诱导的小肠上皮细胞损伤及其 分子机制

目 的: 探讨厚朴酚（Mag）对热应激大鼠小肠上皮细胞 （IEC-6）修复作用，并初步探讨其作用机制。

创新点: 首次在大鼠小肠上皮细胞热应激模型中证明厚朴 酚可明显降低细胞损伤程度, 且此作用与细胞周 期 G1 期相关。
方 法: 本试验采用大鼠小肠上皮细胞 (IEC-6) 为研究 对象, 将其分为五组: 对照组 $\left(37^{\circ} \mathrm{C}, 5 \% \mathrm{CO}_{2}\right)$, 热应激组 $\left(42^{\circ} \mathrm{C}, 3 \mathrm{~h}\right)$, 热应激+厚朴酚低浓度组 $(5 \mu \mathrm{mol} / \mathrm{L})$, 热应激+厚朴酚中浓度组 $(10 \mu \mathrm{mol} / \mathrm{L})$, 热应激+厚朴酚高浓度组 $(20 \mu \mathrm{mol} / \mathrm{L})$ 。采用 MTS 法复制热应激模型及厚朴酚药物浓度篮选; 采用 流式细胞术检测热应激造成大鼠小肠上皮细胞 细胞周期阻滞及不同浓度厚朴酚缓解细胞周期 阻滞情况; 利用电子显微镜观察热应激造成的细 胞损伤情况; 利用苂光电子显微镜观察 EdU 染色 后, 热应激对细胞增殖情况的影响及不同浓度厚 朴酚的修复作用; 采用苂光定量聚合酶链反应 （PCR）技术检测热应激对细胞周期基因表达影 响及不同浓度厚朴酚对细胞周期基因调节作用, 采用蛋白质免疫印迹（Western blot）技术检测热 应激对细胞周期蛋白表达的影响及不同浓度厚 朴酚对细胞周期蛋白修复作用。

结 论: 流式细胞术显示热应激造成 IEC-6 细胞周期阻滞 在 G1 期 (96.5\%), 而三种浓度厚朴酚均可以缓 解细胞周期阻滞现象且呈剂量依赖性 $(5 \mu \mathrm{mol} / \mathrm{L}$ $88.8 \%, 10 \mu \mathrm{mol} / \mathrm{L} 81.0 \%, 20 \mu \mathrm{mol} / \mathrm{L} 73.5 \%$ )。热 应激导致阻滞细胞分裂的 $\mathrm{G} 1$ 期基因 $p 21 、 p 27$ 和 $R b$ 显著上调 $(P<0.01)$, 显示细胞周期阻滞, 不 同浓度厚朴酚下调这三个基因表达且呈剂量依 赖性; 促进细胞分裂的 $\mathrm{G} 1$ 期基因 $E 2 F 1 、 C D K 4$ 和 cyclin $D 1$ 表达显著下调 $(P<0.01)$, 显示细胞 周期阻滞不能正常增值, 厚朴酚有效上调这三个 基因表达水平。热应激导致 G1 期阻滞细胞分裂 蛋白 $\mathrm{p} 21$ 及 $\mathrm{p} 27$ 上调显著 $(P<0.01)$, 厚朴酚有效 下调 p 21 及 $\mathrm{p} 27$ 蛋白表达, 且在 $20 \mu \mathrm{mol} / \mathrm{L}$ 浓度 时效果最佳; 而 $\mathrm{G} 1$ 期促进细胞分裂蛋白 $\mathrm{pRb}$ 、 E2F1、CDK4 和 cyclin D1（CCND1）在热应激下 表达显著下调 $(P<0.01)$, 厚朴酚具有一定上调以 上四个蛋白的作用, 且在 $20 \mu \mathrm{mol} / \mathrm{L}$ 浓度时效果 最佳。厚朴酚作为天然成分药物, 通过缓解热应 激造成的 IEC-6 细胞 G1 期细胞周期阻滞, 具有 缓解热应激造成的细胞损伤能力, 有望作为预防 畜禽热应激的饲料添加剂。

关键词：细胞周期阻滞; 细胞损伤; 热应激; IEC-6; 厚 朴酚 